\title{
Upaya Meningkatan Hasil Belajar Siswa Kelas II Tema 2 Subtema 2 Bermain di Lingkungan Sekolah Melalui Model Pembelajaran Problem Based Learning (PBL) SD Negeri Waru 03
}

\author{
Nurwantinah \\ SD Negeri Waru 03 \\ nurwantinahwaru03@gmail.com
}

\section{Article History}

received 3/12/2020

\begin{abstract}
The background of this research is because of the difficulties experienced by the second grade students of SD Negeri Waru 03, Bantarkawung District, Brebes. It is proven by the percentage of student learning in the previous class of $30 \%$ of students who have completed. The reason is that they feel bored with the monotonous learning process and do not use varied learning methods. The model in this study uses the Problem Based Learning (PBL) model which consists of 4 stages, namely; planning, implementing actions, observing and reflecting. The subjects of this study were second grade students of SD Negeri Waru 03 Bantarkawung District, Brebes Regency for the 2020-2021 academic year with a total of 13 students, consisting of 10 male students and 3 female students.

Data collection techniques using interviews, observation, documentation, and written test assessment. The results of this study can be explained as follows: 1) in the application of the Problem Based Learning (PBL) method there is an increase in teacher and student activity in each cycle, this can be proven for teacher activity in the first cycle to reach a percentage of $80 \%$ (good), while in the second cycle teacher activity reached a percentage of $100 \%$ (very good). Student activity in the first cycle reached a percentage of $69.16 \%$ (good), while in the second cycle it reached a percentage of $90.00 \%$ (very good) so that in the second cycle it was declared successful because it had reached the KKM.
\end{abstract}

Keywords: Problem Based Learning (PBL), learning outcome

\begin{abstract}
Abstrak
Latar belakang dilakukan Penelitian ini karena adanya kesulitan yang dialami siswa kelas II SD Negeri Waru 03 Kecamatan Bantarkawung Kabupaten Brebes. Model dalam penelitian ini menggunakan model Problem Bassed Learning ( $P B L$ ) yang terdiri dari 4 tahap yaitu; perencanaan, pelaksanaan tindakan, observasi dan refleksi. Subjek penelitian ini adalah siswa kelas II SD Negeri Waru 03 Kecamatan Bantarkawung Kabupaten Brebes tahun pelajaran 20202021 dengan jumlah 13 siswa, terdiri dari 10 siswa laki-laki dan 3 siswa perempuan. Teknik pengumpulan data menggunakan wawancara, observasi, dokumentasi, dan penilaian tes tertulis. Hasil penelitian ini dapat dijelaskan sebagai berikut: 1) dalam penerapan metode Problem Bassed Learning (PBL) terdapat peningkatan aktivitas guru dan juga siswa disetiap siklusnya, ini bisa dibuktikan untuk aktivitas guru pada siklus I mencapai prosentase $80 \%$ (baik), sedangkan pada siklus II aktivitas guru mencapai prosentase 100\% (sangat baik). Aktivitas siswa pada siklus I mencapai prosentase $69,16 \%$ (baik), sedangkan pada siklus II mencapai prosentase $90,00 \%$ (sangat baik) sehingga pada siklus II dinyatakan berhasil karena sudah mencapai KKM.

Kata kunci: Problem Based Learning (PBL), hasil belajar
\end{abstract}

Social, Humanities, and Education Studies (SHEs): Conference Series https://jurnal.uns.ac.id/shes

p-ISSN 2620-9284

e-ISSN 2620-9292 


\section{PENDAHULUAN}

Tugas seorang guru dalam menyampaikan materi pelajaran kepada siswa tidaklah mudah. Guru harus memiliki berbagai kemampuan yang dapat menunjang tugasnya agar tujuan pendidikan dapat dicapai. Salah satu kemampuan yang harus dimiliki oleh seorang guru dalam meningkatkan kompetensi profesinya ialah kemampuan mengembangkan metode pembelajaran.

Dalam mengembangkan metode pembelajaran seorang guru harus dapat menyesuaikan antara metode yang dipilihnya dengan kondisi siswa, materi pelajaran, dan sarana yang ada. Oleh karena itu, guru harus menguasai beberapa jenis metode pembelajaran agar proses belajar mengajar berjalan lancar dan tujuan yang ingin dicapai dapat terwujud.

Berdasarkan pengalaman penulis di lapangan, khususnya di daerah-daerah yang sumber daya manusianya masih kurang, guru mengalami kesulitan dalam mengembangkan metode pembelajaran ceramah bervariasikan tanya jawab. Siswa lebih banyak pasif dan merasa takut bila guru mengajukan pertanyaan baik secara lisan maupun tertulis. Hal ini terjadi pula pada siswa kelas II SD Negeri Waru 03.

Berdasarkan hasil refleksi yang dilakukan peneliti sebagai guru kelas II diketahui bahwa masih banyak kekurangan dan kelemahan yang terjadi baik pada peneliti sendiri sebagai guru kelas II dalam menyampaikan atau melasanakan pembelajaran, maupun siswa dalam menerima pembelajaran.

Data tersebut menunjukkan bahwa hasil belajar siswa kelas II dalam materi tema 2 subtema Bermain di lingkungan sekolah dapat dinyatakan belum tuntas. Ketidak tuntasan tersebut terlihat dari bukti prosentase kelulusan seluruh siswa hanya mencapai $30 \%$ dari 13 siswa atau hanya 4 siswa yang mencapai KKM. Prosentase tersebut jauh dari prosentase ideal antara $80 \%$ - 100\%. Bahkan prosentase kelulusan tersebut ternyata lebih kecil dari pada prosentase ketidak lulusan. Oleh karena itu, untuk kasus tersebut perlu diadakan perbaikan proses pembelajaran melalui kegiatan Penelitian Tindakan Kelas (PTK).

Salah satu model pembelajaran yang dapat memaksimalkan hasil belajar siswa adalah model Problem Based Learning (PBL). Model pembelajaran Problem Based Learning (PBL). merupakan model pembelajaran yang dapat mengembangkan potensi siswa untuk berpikir kritis, kreatif, inovatif, dan sistematis (Dasna, 2007:3). Pengunaan model pembelajaran ini diharapkan para siswa dapat memahami materi pelajaran secara utuh, sempurna dan aktif dalam proses pembelajaran, sehingga tidak hanya menguasai pelajaran secara teoritis, tetapi juga mengenal secara operasional. Peserta didik diharapkan mampu menguasai mata pelajaran sehingga hasil belajar mereka melampaui KKM yang telah ditetapkan.

Berdasarkan hal tersebut, peneliti tertarik untuk melakukan penelitian yang berjudul "Upaya Meningkatan Hasil Belajar Siswa Kelas li Tema 2 Subtema 2 Bermain Di Lingkungan Sekolah Melalui Model Pembelajaran Problem Based Learning (PBL) Sd Negeri Waru 03 Kecamatan Bantarkawung Kabupaten Brebes".

Berdasarkan latar belakang tersebut, maka dapat diidentifikasi masalah-masalah sebagai berikut; (1) Hasil belajar siswa kelas II di SD Negeri Waru 03 belum mencapai batas KKM yang sudah ditetapkan oleh sekolah, (1) Guru dalam menyampaikan materi Pembelajaran hanya menggunakan metode ceramah dan gambar diam., (3) Penyampaian materi secara verbal menghambat proses belajar siswa, karena banyak siswa yang mengalami kesulitan dalam memahami materi, (4) Pembelajaran materi tema 2 subtema 2 Bermain di lingkungan sekolah pada siswa kelas II di SD Negeri Waru 03 belum sepenuhnya efektif dan efisien dan masih banyak siswa yang kurang antusias dalam mengikuti pembelajaran, (5) Cara penyajian materi yang kurang menarik sehingga siswa mudah bosan dalam mengikuti pembelajaran.

Kurangnya hasil belajar siswa terhadap kegiatan pembelajaran tema 2 subtema 
2 Bermain di lingkungan sekolah mungkin disebabkan oleh beberapa hal sebagai berikut: Kurangnya motivasi guru melalui materi, metode, dan model pembelajaran yang digunakan, Kurangnya kesempatan untuk belajar sebelum memulai pembelajaran, Kurangnya pemahaman tentang jawaban dari soal yang diberikan, Kurangnya pengadaan media yang menarik dan interaktif, Terkendala sinyal, sehingga materi yang disampaikan tidak maksimal, Siswa kurang menguasai IT sehingga masih terkendala dalam mengumpulkan tugas.

Berdasarkan analisis masalah di atas, penulis mendefinisikan beberapa masalah yakni "Apakah hasil belajar siswa pada materi tema 2 subtema 2 tentang Bermain di lingkungan sekolah kelas II SD Negeri Waru 03 Kecamatan Bantarkawung Kabupaten Brebes dapat meningkat melalui model pembelajaran Problem Based Learning (PBL)?"

\section{METODE}

Sesuai dengan penelitian tindakan kelas model Hopkins, maka sebelum penelitian, langkah pertama yang harus dilakukan adalah mengidentifikasi masalah. Langkah ini dilakukan agar penelitian dapat fokus pada masalah yang telah teridentifikasi tersebut. Masalah dalam penelitian ini tentu saja dalam lingkup kegiatan pembelajaran.

Tindakan pada penelitian ini dilakukan 2 siklus. Langkah-langkah tindakan di setiap siklusnya selalu mengalami perbaikan-perbaikan sampai siklus yang ke II, sebagaimana yang tertuang dalam RPP. Dalam pelaksanaannya, peneliti selalu berusaha untuk mengurangi kelemahan dan berusaha untuk meningkatkan kualitas dalam pembelajarannya.

Untuk memecahkan masalah dalam penelitian diperlukan data yang relevan dengan permasalahannya, sedangkan untuk mendapatkan data tersebut perlu digunakan teknik pengumpulan data yang tepat. Teknik pengumpulan data yang digunakan dalam penelitian adalah tes, observasi, dokumentasi dan wawancara.

Adapun teknik analisis data yang digunakan untuk mengetahui peningkatan hasil belajar siswa pada penelitian ini yakni dengan membandingkan persentase ketuntasan belajar dalam penerapan model pembelajaran Problem Based Learning (PBL) pada siklus I dan siklus II. Sedangkan persentase ketuntasan belajar dihitung dengan cara membandingkan jumlah siswa yang tuntas belajar dengan jumlah siswa secara keseluruhan (siswa maksimal) kemudian dikalikan 100\%.

\section{HASIL DAN PEMBAHASAN}

Hasil Penelitian Tindakan Kelas ini akan dideskripsikan berdasarkan permasalahan yang ada pada rumusan masalah. Penelitian Tindakan Kelas ini memperoleh data dari setiap tes tindakan, hasil observasi terhadap siswa dan guru, hasil tes soal dan Lembar Kerja Siswa. Penelitian ini dilaksanakan dalam 2 siklus dengan 1 tindakan pada setiap siklusnya, meliputi perencanaan, pelaksanaan, observasi dan refleksi. Untuk mengetahui hasil penelitian ini secara lebih rinci dan jelas dapat diketahui pada pengolahan data di bawah ini:

\section{Pra Siklus}

Berdasarkan hasil refleksi yang dilakukan peneliti sebagai guru kelas II diketahui bahwa masih banyak kekurangan dan kelemahan yang terjadi baik pada peneliti sendiri sebagai guru kelas II dalam menyampaikan atau melasanakan pembelajaran, maupun siswa dalam menerima pembelajaran.

Data tersebut menunjukkan bahwa hasil belajar siswa kelas II SD Negeri Waru 03 Kecamatan Bantarkawung Kabupaten Brebes dalam materi tema 2 subtema 1 tentang Bermain di lingkungan rumah dapat dinyatakan belum tuntas. Ketidak tuntasan tersebut terlihat dari bukti prosentase kelulusan seluruh siswa hanya mencapai 30\% dari 12 siswa atau hanya 4 siswa yang mencapai KKM. Prosentase tersebut jauh dari prosentase ideal antara $80 \%-100 \%$. Bahkan prosentase kelulusan tersebut ternyata lebih kecil dari pada 
prosentase ketidak lulusan. Oleh karena itu, untuk kasus tersebut perlu diadakan perbaikan proses pembelajaran melalui kegiatan Penelitian Tindakan Kelas (PTK).

Berdasarkan data yang diperoleh rata-rata kelas 69,16 dengan persentase $69 \%$ dikatakan cukup baik. Peningkatan belajar pada siklus I sebesar $69 \%$ yang berarti $69 \%$ siswa sudah mendapatkan nilai diatas ataupun sama dengan KKM. Dari data yang diperoleh, pada siklus I belum mencapai rata-rata kelas dan peningkatan belajar yang ideal yang telah ditargetkan peneliti. Dengan persentase rata-rata kelas ideal adalah $80 \%$ dan persentase peningkatan belajar siswa adalah $100 \%$. Berdasarkan data-data yang diperoleh, peneliti menarik kesimpulan bahwa pelaksanaan siklus I masih kurang baik dalam pelakasanaannya. Terlihat dari nilai hasil evaluasi siswa, observasi guru dan observasi siswa.

Hasil dari observasi guru pada siklus I dan II juga mengalami peningkatan. Dapat dilihat dari tabel 1 dibawah ini:

Tabel 1. Hasil Observasi Guru (Peneliti)

\begin{tabular}{ccc}
\hline No & Tindakan & Persentase (\%) \\
\hline 1 & Siklus I & 100 \\
2 & Siklus II & 100 \\
\hline
\end{tabular}

Selain dengan tabel 1 dapat dilihat juga pada grafik dibawah ini untuk melihat hasil dari observasi guru (peneliti) di setiap siklusnya.

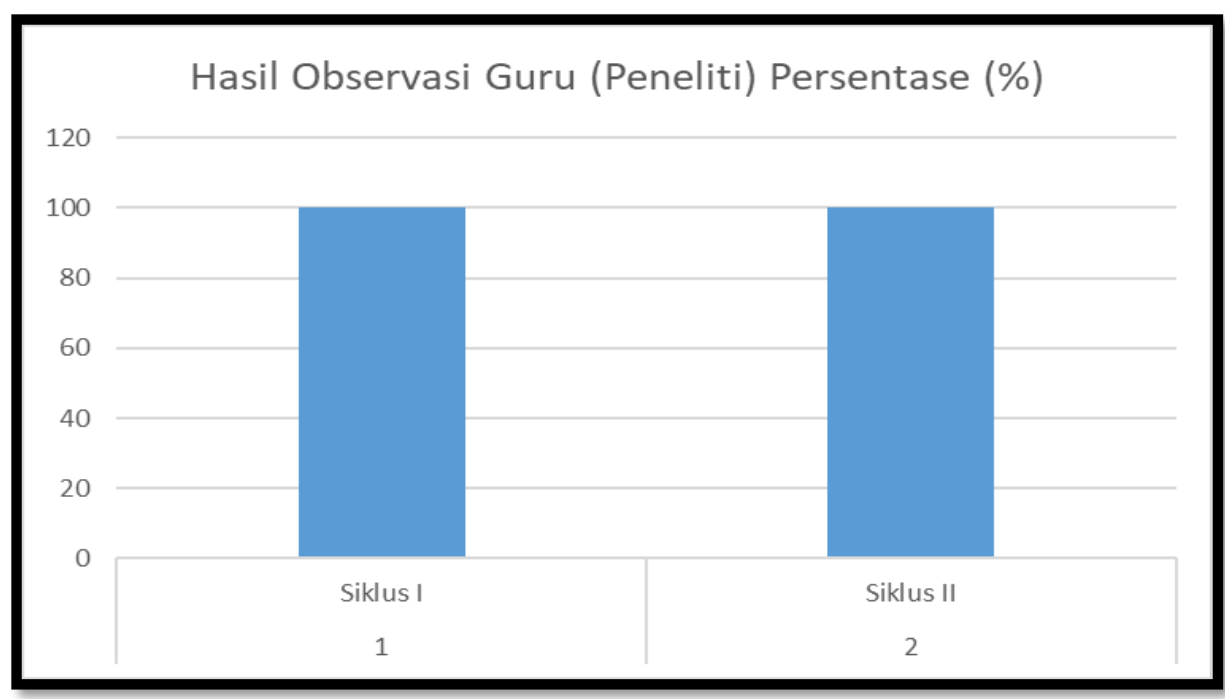

Gambar 1. Grafik Hasil Observasi Guru (Peneliti)

Dari grafik 4.2 dapat dilihat bahwa pada siklus I guru sudah melaksanakan seluruh proses pembelajaran dengan baik, terbukti bahwa semua poin telah dilaksanakan guru. Namun dalam kegiatan pembelajaran masih belum maksimal. Hal ini menyatakan bahwa pembelajaran dengan model Problem Bassed Learning (PBL) belum sepenuhnya terlaksana dengan baik. 
Pada siklus II pelaksanaan pembelajaran dapat dikatakan baik, dilihat dari kinerja guru yang sudah baik dan pelaksanaan yang sudah sesuai dengan perencanaan. Karena pada siklus II ini guru sudah terbiasa menggunakan media zoom meeting dengan model Problrm Bassed Learning (PBL) dan sudah dapat mengkondisikan kelas dengan baik secara daring.

Peningkatan hasil belajar siswa dari prasiklus, siklus I dan II dapat dilihat peningkatannya melalui tabel 2 berikut:

Tabel 2. Hasil Belajar Siswa Setiap Siklus

\begin{tabular}{clcc}
\hline No. & Tindakan & Rata-rata Kelas (\%) & Tuntas (\%) \\
\hline 1. & Prasiklus & 30 & $30 \%$ \\
2. & Siklus I & 69 & $69,16 \%$ \\
3. & Siklus II & 90 & $90,00 \%$ \\
\hline
\end{tabular}

Selain itu, peningkatan hasil belajar siswa disajikan pula dalam bentuk grafik. Untuk melihat peningkatan hasil evaluasi siswa pada setiap siklus yaitu dapat dilihat pada grafik berikut:

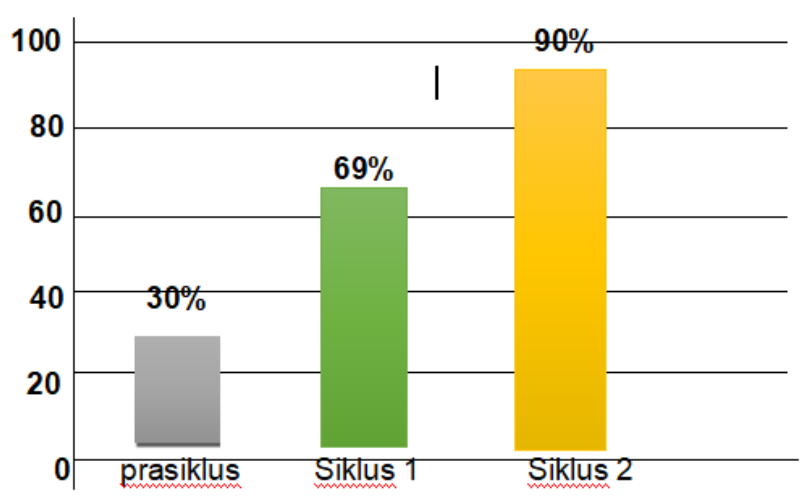

Gambar 2. Grafik peningkatan hasil belajar

Dilihat dari grafik terlihat peningkatan hasil evaluasi dan ketuntasan belajar siswa dari prasiklus, siklus I sampai siklus II. Terlihat bahwa pada prasiklus, siklus I dihasilkan persentase rata-rata siswa $69 \%$ dan pada siklus II prosentase rata-rata kelas adalah sebesar $90 \%$ (sudah mencapai target peneliti).

Model pembelajaran PBL (problem based learning) adalah sistem pembelajaran yang berpijak pada masalah yang dihadapi siswa pada saat proses mendapatkan ilmu pengetahuan. Ini berfungsi agar siswa bisa mandiri dalam menemukan solusi berdasarkan masalah yang ada.

Dalam prosesnya, pembelajaran PBL atau dalam bahasa Indonesia berarti Pembelajaran Berbasis Masalah (PBM). Memanfaatkan strategi yang lebih sistematik untuk menemukan solusi dari masalah yang ada dalam kehidupan sehari-hari pada siswa.

Dengan adanya landasan strategi ini, siswa bisa menuai hasil dari PBL sebagai pola pikir di masa depan guna menemukan solusi dari berbagai macam masalah yang akan dihadapi. Sehingga problematika dalam hidup akan berangsur-angsur teratasi.

Resume pembelajaran PBL ini menurut J. Duch (1994) adalah instruksi kepada siswa untuk selalu belajar. Menciptakan kolaborasi yang solid dalam suatu grup untuk 
memecahkan masalah yang ada. Materi masalah yang dibuat guru untuk siswa, bermanfaat untuk menumbuhkan kecakapan dalam analisis, inisiatif dan kritis yang mana nantinya akan terbenam pada pola pikir peserta didik.

Sanjaya (2006: 214): PBL adalah susunan kegiatan pembelajaran yang bertumpu pada pemecahan masalah dengan cara ilmiah. Esensi dari permasalahan yang didaulat pada pembelajaran problem based learning ini adalah ketimpangan antara ideal dan realitas yang diharapkan, atau bisa dikaitkan gap antara cita-cita dengan realitas.

Kelebihan Model Problem Bassed Learning (PBL)

1) Penemuan solusi adalah metode paling signifikan untuk bisa memahami pengetahuan

2) Problem solving bisa memicu pembelajar untuk lebih lapar dengan ilmu pengetahuan.

3) Pemecahan masalah bisa menumbuhkan semangat siswa dalam kegiatan belajar.

4) Bisa bermanfaat untuk menemukan cara agar menerangkan pengetahuan kepada orang lain.

5) Memberikan rasa tanggung jawab dalam belajar. Selain itu penemuan solusi ini juga mengembangkan siswa untuk bisa refleksi diri terhadap proses belajar.

6) Siswa bisa mengetahui bahwa setiap pembelajaran pada hakikatnya adalah cara berpikir, tidak hanya belajar melalui buku dan guru secara mentah.

7) Dengan metode pemecahan masalah siswa cenderung lebih bersemangat dan menyukai dalam proses pembelajaran.

8) Metode PBL melatih siswa untuk berpikir kritis dan bisa mencerna pengetahuan baru secara solid.

9) Berguna untuk siswa agar bisa memakai pengetahuan yang dimiliki di dunia nyata.

10) Model PBL bisa berguna untuk memicu siswa untuk secara konsisten untuk terus belajar. Meskipun belajar di jenjang formal sudah berakhir.

Pada pembahasan ini akan membahas tentang hasil penelitian mengenai meningkatkan hasil belajar siswa pada materi tema 2 subtema 2 Bermain di lingkunganku. Penelitian ini diawali dengan observasi awal di sekolah untuk menenentukan masalah-masalah yang ada di sekolah khususnya di kelas II tersebut. Observasi awal dilaksanakan pada saat peneliti melaksanakan Praktik Pengalaman Lapangan (PPL).

Kemudian peneliti mengambil kesimpulan dari kelas yang biasa diajarnya, yaitu dengan menggunakan model Problem Bassed Learning (PBL) materi tema 2 subtema 2 untuk meningkatkan hasil belajar siswa kelas II SDN Waru 03 Kecamatan Bantarkawung, Kabupaten Brebes. Peneliti melakukan penelitian di kelas II dan mendapatkan beberapa hasil dari hasil belajar siswa.

Hasil observasi guru dari siklus I dan II mengalami peningkatan dari siklus I guru masih kurang dalam pemberian video pembelajaran yang kurang terpadu. pada siklus II, peneliti melakukan perbaikan dari siklus I sehingga pada siklus II ini pelaksanaan pembelajaran sudah baik.

Hasil observasi siswa dari siklus I dan II juga mengalami peningkatan. Pada siklus I siswa masih kurang kondusif dalam pembelajaran, ini dikarenakan siswa masih belum terbiasa terhadap pembelajaran yang menggunakan media zoom meeting dan melalui daring. Sedangkan pada siklus II, pembelajaran sudah baik dilaksanakan. Selain itu, pembelajaran tema 2 subtema 2 dengan menggunakan media zoom meeting sudah dapat berkesan dalam diri peserta didik. Ini dibuktikan dengan adanya pertanyaan dari siswa yang mempertanyakan apa yang mereka lihat dengan materi yang telah disampaikan pada siklus sebelumnya.

Hasil belajar siswa merupakan hasil evaluasi siswa. Hasil evaluasi siswa mengalami peningkatan dari siklus I dan II. Untuk hasil belajar siklus I, rata-rata kelas yang diperoleh adalah sebesar $69,16 \%$ ) dan pada siklus II rata-rata kelas sebesar 90,00 $(90 \%)$, ini berarti sudah mencapai target yang telah ditentukan peneliti (80). Dari 
ketuntasan belajar juga mengalami peningkatan dari siklus I hingga siklus II. Pada siklus I, ketuntasan belajar siswa sebesar 58\%. dan pada siklus II ketuntasan belajar sudah mencapai $100 \%$.

\section{SIMPULAN}

Berdasarkan pembahasan dan hasil penelitian maka dapat disimpulkan sebagai berikut pembelajaran dengan menggunakan model pembelajaran Problem Bassed Learning (PBL) materi tema 2 subtema 2 Benda di Sekitarku SD Negeri Waru 03 Kecamatan Bantarkawung Kabupaten Brebes dapat meningkatkan proses pembelajaran. Dimana dilihat dari peningkatan rata-rata diperoleh adalah sebesar $69,16 \%$ (69) pada siklus I dan pada siklus II 90,00\% (90) ini berarti sudah mencapai target yang telah ditentukan peneliti (80). Dari ketuntasan belajar juga mengalami peningkatan dari siklus I, keteuntasan belajar siswa sebesar $58 \%$ dan pada siklus II ketuntasan belajar sudah mencapai $100 \%$.

Tindak lanjut dari Penelitian Tindakan Kelas ini, perlu diupayakan penelitianpenelitian lain. Hal ini diupayakan agar peneliti lain dapat mengkaji teori-teori yang berkaitan dengan penggunaan media pembelajaran sebagai salah satu alterntif untuk meningkatkan hasil belajar siswa yang belum terdapat dalam penelitian ini, terutama materi tema 2 subtema 2 "Bermain di lingkungan rumah".

\section{DAFTAR PUSTAKA}

Dasna, 2007:3. Model pembelajaran Problem Based Learning (PBL).

Endang Mulyatiningsih (2011:60-63) karakteristik penelitian tindakan kelas

Finkle dan Torp (dalam Shomin 2014: 130) mengungkapkan pengembangan kurikulum dan sistem pengajaran

Kemendikbud.2018.BukuTematik Terpadu Kurikulum 2013 kelas 2 Tema 2. Bermain di lingkunganku (Buku Siswa - Revisi Tahun 2018). Jakarta: Kemendikbud.

Kemendikbud.2018.Buku Tematik Terpadu Kurikulum 2013 kelas 2 Tema 2. Bermain dilingkunganku (Buku Guru - Revisi Tahun 2018). Jakarta: Kemendikbud.

Robertus Angkoro dan A. Kosasih, 2007: 50-51. karakteristik individu, kualitas pengajaran, dan hasil belajar siswa

Resume pembelajaran PBL ini menurut J. Duch (1994)

Sanjaya (2006: 214): Tentang model pembelajaran Problem Bassed Learning (PBL)

Wijaya Kusuma (2009:9) tentang penelitian tindakan kelas. 